\title{
The Development Strategy for the Food and Beverage Service Study Program as One of the Superior Study Programs at the Politeknik Pariwisata Makassar
}

\author{
Ratnah $^{1}$, I Putu Suarta ${ }^{2}$, Rita $^{3}$ \\ ${ }^{1,2,3}$ Politeknik Pariwisata Makassar \\ Email: ratna.poltekpar@gmail.com
}

(Received: August 2020; revised: September 2020; published: October 2020)

\begin{abstract}
The interest of students to continue studying at the Politeknik Pariwisata Makassar is very large and increases from year to year.. This study aims to formulate a development strategy for the Food and Beverage Service Management study program as one of the superior study programs at Makassar Tourism Polytechnic. This research uses descriptive quantitative method. Respondents in this study totaled 241 consisting of 140 male respondents and 101 female respondents who were a combination of students, lecturers/staff of the Food and Beverage Service study program at Makassar Tourism Polytechnic, hotel/restaurant employees, entrepreneurs, employees of other companies, and that hasn't worked. The data collection techniques used in this study were: questionnaires, interviews, Focus Group Discussion (FGD), and literature study. The data analysis technique was carried out in three stages, namely the input stage, the matching stage and the decision stage. The conclusion of this research is that the analysis results from the IFAS matrix show that the strength factor of the study program is much greater than the weakness factor so that the study program has strengths or advantages that can be developed. Meanwhile, the results of the analysis from the EFAS matrix show that the opportunities the study program has are greater than the threat factors so that the study program has a greater chance of being developed. As for the results of the QSPM matrix analysis, the TAS value that has been listed is that the W-O strategy gets the highest value of 6,354, the W-T strategy is 6,027 then the S-O strategy is 5,976 and finally the S-T strategy is 5,869. That is, the development strategy of the MTH study program is compiled in 14 priority strategies from 20 formulated strategies consisting of the W - O Strategy (5 strategies), the W - T Strategy (4 strategies), the S - O Strategy (3 strategies), and the S - T (2 strategies).
\end{abstract}

Keywords: Development Strategy, IFE Matrix, EFE Matrix, QSPM

\section{INTRODUCTION}

The interest of students to continue studying at the Makassar Tourism Polytechnic (Poltekpar Makassar) is very large and increases from year to year. Students who are interested in studying at the Makassar Poltekpar in 2018 are 4,705 people (1,778 people on the SBMPTNP pathway and 2927 people on the SMM pathway) and have increased in 2019 to 7,958 (1533 on the SBMPTNP route and 6425 on the SMM route) or an increase 59\%. However, the increase in the number of enthusiasts and participants was not evenly distributed for each study program including the Food and Beverage Service study program.

Based on data on new student admissions, the number of students admitted to the MTH study program, in previous years, always corresponds to the specified capacity. However, at the 2019 new student admission, the target number of students accepted for the MTH study 


\author{
216 Jurnal Administrare: Jurnal Pemikiran Ilmiah dan Pendidikan Administrasi Perkantoran \\ Volume 7 Number 2 July- December 2020. Pages 215-226
}

program is 80 students, but only 72 people are accepted. This shows that the number of students accepted does not match the predetermined target. Therefore, the importance of a study program development strategy in order to increase the number of enthusiasts who choose Poltekpar, especially the course of Food and Beverage Service.

According to (Sofjan, 2013) the function of the strategy is basically to streamline the implementation in helping achieve organizational goals. There are six strategic functions that must be carried out simultaneously, namely: (1) communicating a purpose (vision) to be achieved to others, (2) connecting or linking the strengths or advantages of the organization with opportunities from its environment, (3) exploiting or exploiting success and the success that is obtained now is simultaneously investigating the existence of new opportunities, (4) generating and generating more resources than currently used, (5) coordinating and directing future activities or organizational activities, and (6) responding and react to new situations all the time.

The strategy is a fundamental pattern of current and planned goals, mobilization of resources, and interactions of the organization with markets, competitors, and other environmental factors (Boyd \& Harper, 2000). The strategy is a long-term plan, followed by actions aimed at achieving a specific goal, which is generally victory. The term strategy is formulated as a goal to be achieved and the steps to achieve that goal (Astuti, Silalahi, \& Wijaya, 2015; Botituhe, Akib, \& Gani, 2017.; Kurniawati, Triyanti, \& Daraba, 2019; Sedarmayanti, 2018)

According to (Setyosari, 2012) that development activities include three stages, namely planning, implementing, and evaluating followed by improvement activities so that a form deemed adequate is obtained. Development is a process or effort to make a change either slowly or gradually by deepening and expanding existing knowledge through the planning, implementation, and evaluation process. (Ibrahim, Boerhannoeddin, \& Kazeem Kayode, 2017; Prasodjo, 2020; Rasyid, 2020)

The formulation of the development strategy for the Food and Beverage Service study program, the writer will use the matrix analysis External Factor Evaluation (EFAS), Internal Factor Evaluation (IFAS), SWOT, and Quantitative Strategic Planning Matrix (QSPM). Matrix External Factor Evaluation (EFAS) is part of an organization's external audit. The EFE matrix is used to evaluate the external factors of the organization. Its purpose is to develop a finite list of opportunities that can benefit an organization and threats to avoid. In addition, the external evaluation identifies important variables that offer responses in the form of actions. In this case, an organization must be able to respond in the form of action (Klein, 2009). Meanwhile, the IFE matrix is used to determine internal organizational factors related to strengths and weaknesses that are considered important. The internal aspects of the organization can be extracted from several organizational functions, such as finance, human resources, management, competence, marketing, production, and so on (Evelyn, 2018).

\title{
METHOD
}

This research uses a quantitative approach, with a descriptive method because this research will look for facts in the field using proper interpretations of relationships, activities, attitudes, views, and ongoing processes related to management study program development 
strategies. food preparation as one of the superior study programs at the Politeknik Pariwisata Makassar (Herdiansyah, 2010; Sugiyono, 2017). The operational definitions in this research are: (1) strategy is defined as a goal to be achieved and steps to achieve that goal, (2) development is defined as a process or effort to make a change either slowly or gradually by deepening and expand existing knowledge through planning, implementation and evaluation processes.

This research was conducted in several places, namely the Politeknik Pariwisata Makassar and several starred hotels/restaurants in Makassar, as well as several districts and cities that are considered representative in South Sulawesi province, namely Makassar City, Parepare City, Bone Regency, and Bulukumba Regency. Respondents/informants in this study totaled 241 consisting of 140 male respondents and 101 female respondents who were a combination of students, lecturers/staff of the Politeknik Pariwisata Makassar Food and Beverage Service study program, hotel/restaurant employees, entrepreneurs, employees of other companies, and that hasn't worked. The data collection techniques used in this study were: questionnaires, interviews, Focus Group Discussion (FGD), and literature study. As part of the data analysis technique, developing a development strategy is carried out by going through three stages of analysis, namely the input stage, namely by entering the results of EFAS (External Factor Analysis) and IFAS (Internal Factor Analysis) into the matrix, the merger stage ( Matching Stage) by combining the results from the EFAS and IFAS matrices into the SWOT analysis and the decision stage. The final stage of this data analysis is to formulate the decisions that will be taken in the QSPM (Quantitative Strategic Planning Matrix) process.

\section{RESULT AND DISCUSSION}

\section{Internal Factors Analysis Summary (IFAS)}

IFAS describes the magnitude of the influence between internal factors on the strategymaking of an organization or business (Rangkuti, 2016).

\section{Tabel 1.}

\section{Internal Factors Analysis Summary (IFAS)}

\begin{tabular}{|c|c|c|c|c|c|}
\hline No & Strength Factors & Code & Quality & Rating & Score \\
\hline 1 & $\begin{array}{l}\text { Has status as a country under the auspices of } \\
\text { the Ministry of Tourism and Creative } \\
\text { Economy }\end{array}$ & S1 & 0.063 & 4 & 0.252 \\
\hline 2 & Received Accreditation A from BAN-PT & S2 & 0.063 & 4 & 0.252 \\
\hline 3 & $\begin{array}{l}\text { The alumni get a competency certificate } \\
\text { from BNSP in addition to a diploma }\end{array}$ & S3 & 0.063 & 4 & 0.252 \\
\hline 4 & $\begin{array}{l}\text { Cheap tuition fees because it gets subsidies } \\
\text { from the government }\end{array}$ & S4 & 0.063 & 4 & 0.252 \\
\hline 5 & $\begin{array}{l}\text { Consists of several outlets (Restaurant, Bar, } \\
\text { Room Service, Banquet) }\end{array}$ & S5 & 0.063 & 4 & 0.252 \\
\hline 6 & $\begin{array}{l}\text { There is budget support from the ministry } \\
\text { for the development of the MTH study } \\
\text { program }\end{array}$ & S6 & 0.063 & 4 & 0.252 \\
\hline
\end{tabular}



218 Jurnal Administrare: Jurnal Pemikiran Ilmiah dan Pendidikan Administrasi Perkantoran
Volume 7 Number 2 July- December 2020. Pages $215-226$

7 Have cooperation with industry

8 Have lecturers who are competent in the S7

$\begin{array}{ll}0.048 & 3\end{array}$

0.144 field of FBS

9 Has international standard facilities and

S8

0.048

3

0.144

infrastructure

10 The curriculum applied is a competency-

S9

$$
0.063
$$

4

0.252

based curriculum

$\begin{array}{llll}\mathrm{S} 10 & 0.063 & 4 & 0.252\end{array}$

Total

\begin{tabular}{|c|c|c|c|c|c|}
\hline & Weakness Factor & Code & Ouality & Rating & Score \\
\hline 1 & $\begin{array}{l}\text { New students who were accepted have } \\
\text { average abilities }\end{array}$ & W1 & 0.032 & 2 & 0.064 \\
\hline 2 & $\begin{array}{l}\text { Most of the new students who are accepted } \\
\text { do not have a background in hospitality, } \\
\text { especially about FBS. }\end{array}$ & W2 & 0.048 & 3 & 0.144 \\
\hline 3 & $\begin{array}{l}\text { The role of the alumni association is not } \\
\text { active in providing input on the development } \\
\text { of the MTH study program }\end{array}$ & W3 & 0.032 & 2 & 0.064 \\
\hline 4 & Students' English competency is still lacking & W4 & 0.048 & 3 & 0.144 \\
\hline 5 & $\begin{array}{l}\text { Promotion for the MTH Study Program is } \\
\text { less explored online, through social media } \\
\text { and institutional websites and the MTH } \\
\text { study program web }\end{array}$ & W5 & 0.048 & 3 & 0.144 \\
\hline 6 & $\begin{array}{l}\text { The courses taught are not entirely } \\
\text { technology-based }\end{array}$ & W6 & 0.032 & 2 & 0.064 \\
\hline 7 & $\begin{array}{l}\text { Most students who are admitted are not the } \\
\text { first choice at the time of registration }\end{array}$ & W7 & 0.048 & 3 & 0.144 \\
\hline 8 & $\begin{array}{l}\text { Lack of learning activities that can improve } \\
\text { student competence in having data, } \\
\text { technology, and human literacy }\end{array}$ & W8 & 0.032 & 2 & 0.064 \\
\hline 9 & $\begin{array}{l}\text { In cooperation with the industry it is still } \\
\text { limited to placing PKN }\end{array}$ & W9 & 0.032 & 2 & 0.064 \\
\hline 10 & $\begin{array}{l}\text { Lack of financial support to include students } \\
\text { in competitions in the field of FB }\end{array}$ & W10 & 0.048 & 3 & 0.144 \\
\hline & Total & & & & 1.040 \\
\hline
\end{tabular}

Based on the results of the IFAS matrix with a weight of 1.0 , the weight score is 3,344 with a weighted score for the strength factor of 2,304, while the weakness factor is 1,040 . This shows that the strength factor of the study program is much greater than the weakness factor so that the study program has strengths or advantages that can be developed. 


\section{External Factors Analysis Summary (EFAS)}

EFAS describes the magnitude of the influence between external factors on the strategymaking of a company or business (Rangkuti, 2016).

Table 2.

External Factors Analysis Summary (EFAS)

\begin{tabular}{|c|c|c|c|c|c|}
\hline No & Opportunity Factor & Code & Quality & Rating & Score \\
\hline 1 & $\begin{array}{l}\text { The increasing number of high school } \\
\text { graduates in the city of Makassar and in } \\
\text { the Province of South Sulawesi }\end{array}$ & $\mathrm{O} 1$ & 0.056 & 3 & 0.168 \\
\hline 2 & $\begin{array}{l}\text { Many SMK and SMA graduates prefer to } \\
\text { study at vocational colleges }\end{array}$ & $\mathrm{O} 2$ & 0.037 & 2 & 0.074 \\
\hline 3 & $\begin{array}{l}\text { The development of the hospitality } \\
\text { industry is growing }\end{array}$ & $\mathrm{O} 3$ & 0.056 & 3 & 0.168 \\
\hline 4 & $\begin{array}{l}\text { The number of alumni who have } \\
\text { occupied strategic positions in the hotel } \\
\text { industry, especially in the FB section }\end{array}$ & $\mathrm{O} 4$ & 0.056 & 3 & 0.168 \\
\hline 5 & $\begin{array}{l}\text { There are scholarships for } \\
\text { underprivileged and outstanding students }\end{array}$ & O5 & 0.074 & 4 & 0.296 \\
\hline 6 & $\begin{array}{l}\text { There are opportunities for promotion } \\
\text { both in South Sulawesi Province and } \\
\text { outside South Sulawesi }\end{array}$ & O6 & 0.056 & 3 & 0.168 \\
\hline 7 & $\begin{array}{l}\text { The availability of supporting activities } \\
\text { for the development of skills or skills }\end{array}$ & $\mathrm{O} 7$ & 0.056 & 3 & 0.168 \\
\hline 8 & $\begin{array}{l}\text { Many job vacancies require a graduate } \\
\text { from MTH }\end{array}$ & O8 & 0.056 & 3 & 0.168 \\
\hline 9 & $\begin{array}{l}\text { The competencies taught are relevant to } \\
\text { industry needs }\end{array}$ & O9 & 0.056 & 3 & 0.168 \\
\hline 10 & $\begin{array}{l}\text { There are opportunities for students to } \\
\text { take part in competitions in the field of } \\
\text { FB, whether local, national, or } \\
\text { international. }\end{array}$ & $\mathrm{O} 10$ & 0.056 & 3 & 0.168 \\
\hline & Total & & & & 1.714 \\
\hline No & Threat Factors & Code & Quality & Rating & Score \\
\hline 1 & $\begin{array}{l}\text { The number of higher education } \\
\text { institutions who have switched to the } \\
\text { Polytechnic }\end{array}$ & $\mathrm{T} 1$ & 0.037 & 2 & 0.074 \\
\hline 2 & $\begin{array}{l}\text { The emergence of universities that open } \\
\text { tourism study programs }\end{array}$ & $\mathrm{T} 2$ & 0.037 & 2 & 0.074 \\
\hline 3 & $\begin{array}{l}\text { Many universities have opened new } \\
\text { admissions earlier and have announced }\end{array}$ & $\mathrm{T} 3$ & 0.037 & 2 & 0.074 \\
\hline
\end{tabular}


22d Jurnal Administrare: Jurnal Pemikiran Ilmiah dan Pendidikan Administrasi Perkantoran Volume 7 Number 2 July- December 2020. Pages 215-226

\begin{tabular}{llllll}
\hline & the results & & & & \\
\hline 4 & $\begin{array}{l}\text { There is a Joint Entry Selection (SBM) at } \\
\text { 6 PTNP }\end{array}$ & T4 & 0.055 & 0.165 \\
\hline 5 & $\begin{array}{l}\text { The opening of the Diploma IV program } \\
\text { at the Politeknik Pariwisata Makassar in } \\
\text { hospitality }\end{array}$ & T5 & 0.055 & 3 & 0.165 \\
\hline 6 & The development of online food ordering & T6 & 0.055 & 3 & 0.165 \\
\hline 7 & $\begin{array}{l}\text { The entrance selection examination } \\
\text { system is still manual }\end{array}$ & T7 & 0.037 & 2 & 0.074 \\
\hline 8 & $\begin{array}{l}\text { Hospitality SMK graduates have almost } \\
\text { the same competencies as D III MTH } \\
\text { graduates }\end{array}$ & T8 & 0.037 & 2 & 0.074 \\
\hline 9 & $\begin{array}{l}\text { The community wants their children to } \\
\text { study up to a bachelor's degree (S1 or } \\
\text { DIV) }\end{array}$ & T9 & 0.055 & 3 & 0.165 \\
\hline 10 & $\begin{array}{l}\text { The public image about tourism, } \\
\text { especially for working on the FBS } \\
\text { department is still negative }\end{array}$ & T10 & 0.037 & 2 & 0.074 \\
\hline$\quad$ Total & & $\mathbf{1 . 0}$ & & $\mathbf{1 . 1 0 4}$ \\
\hline
\end{tabular}

Based on the results of the EFAS matrix analysis above, it can be seen that with Bobo 1.0 a weighted score of 2.818 is obtained, with details for the opportunity factor score of 1.714 while the threat factor is obtained 1.104. This shows that the opportunities that the study program has are greater than the threat factor so that the study program has a greater chance of being developed..

\section{Matching Stages and Strategy Formulation}

After the data were analyzed with the IFAS and EFAS matrices, a combined stage was carried out in the SWOT analysis to identify the strengths, weaknesses, opportunities, and threats that were installed in the framework of strategy formulation. Strategy formulation is one step in combining or matching each factor in order to produce an alternative strategy. The analysis used in combining or matching each factor is the SWOT analysis. With the SWOT analysis, four forms will be generated as a combination of two factors, namely (1) SO strategy (as a combination of strength and opportunity factors), (2) ST strategy (as a combination of strength and threat factors), (3) WO strategy (as a merger weakness and opportunity factors), and (4) WT strategy (as a combination of weakness and threat factors).

The results of combining or matching each factor in producing the following strategy formulations: 
1. S-O Strategy (Strength - opportunities)

a. Promotion activities are further enhanced by involving study programs to highlight all products, outlets, job opportunities, and graduate profiles (S1, S5, O6, O8)

b. Cooperating with alumni in promoting study programs and providing information on job opportunities in the industry/company where the alumni work. (S7, O4, O6, O8)

c. Involving students actively in every competition or event that can introduce study programs to the community (S6, O6, O10)

d. Maximizing the use of facilities and infrastructure, especially technology-based equipment in increasing the competence of lecturers and students (S8, S9, O9)

e. Curriculum reviews are carried out periodically based on industrial needs (S3, S10, O9)

2. S-T Strategy (Strength - Threats)

a. The study program must create a logo that accentuates products from the restaurant and not on services (S3, S5, T8, T10)

b. The study program creates profiles that further highlight products and capabilities in restaurant management, including displaying top-level positions in the restaurant, not service profiles that carry trays (S3, S5, T8, T10)

c. Collaboration with industry in developing lecturer competence must always be carried out regularly to improve the quality/competence of graduates (S7, S8, T8)

d. The study program must often carry out community service activities together with students to improve its image (S6, T10)

e. Upgrading the status from D-III program to D-IV program with the name of "Restaurant Management" study program (S1, S8, T5, T9)

3. W-O Strategy (Weaknesses - Opportunities)

a. Maximizing the implementation of extra-curricular activities in improving student competence (W1, O7, O9)

b. Regularly involve alumni as Guest Lecturers to increase knowledge, insight, skills, and motivation to students so that they are proud of the study program (W1, W2, W7, O4)

c. Provide activities for students to use English optimally, for example when entering a restaurant, or when serving guests and on extra-curricular activities (W4, O7, O9)

d. Coordination between study programs is further improved so that the implementation of practice can run optimally (W6, W8, O9)

e. Cooperation with industry in implementing PKN is further enhanced including providing facilities to students (W9, O8, O9)

4. W - T (Weaknesses - Threats) Strategy

a. Maximizing the lecture process both theory and practice in improving student competence (W1, W4, T8)

b. Providing orientation or hotel visits to new students (W2, T8)

c. Provide training more often to the community and include students in various competitions and events to give a good image (W5, W7, T10)

d. Creating a "magic word" that can increase the enthusiasm and pride of students in their study program (W7, T10)

e. Prepare the study program to switch to the D-IV program using the name of the study program "Restaurant Management" or Restaurant Management (W2, T9) 
222 Jurnal Administrare: Jurnal Pemikiran Ilmiah dan Pendidikan Administrasi Perkantoran
Volume 7 Number 2 July- December 2020. Pages 215-226

\section{Decision Stage}

After the data has been analyzed with IFAS, EFAS and SWOT, then QSPM matrix analysis will be carried out as a stage in decision making. The results of the analysis of the QSPM calculation can be seen in the following table.

Table 3.

QSPM Matrix

\begin{tabular}{|c|c|c|c|c|c|c|c|c|c|}
\hline \multirow{3}{*}{ Strategic Factors } & \multirow{3}{*}{ Quality } & \multicolumn{8}{|c|}{ Alternative Strategies } \\
\hline & & \multicolumn{2}{|c|}{ SO strategy } & \multicolumn{2}{|c|}{ ST strategy } & \multicolumn{2}{|c|}{ WO strategy } & \multicolumn{2}{|c|}{ WT strategy } \\
\hline & & AS & TAS & AS & TAS & AS & TAS & $\mathbf{A S}$ & TAS \\
\hline \multicolumn{10}{|l|}{ Strengths } \\
\hline - Status & 0.063 & 3 & 0.189 & 3 & 0.189 & 4 & 0.252 & 4 & 0.252 \\
\hline - Accreditation & 0.063 & 4 & 0.252 & 4 & 0.252 & 3 & 0.189 & 3 & 0.189 \\
\hline $\begin{array}{l}\text { - Competency } \\
\text { Certificate }\end{array}$ & 0.063 & 4 & 0.252 & 4 & 0.252 & 3 & 0.189 & 3 & 0.189 \\
\hline - Tuition fee & 0.063 & 3 & 0.189 & 3 & 0.189 & 4 & 0.252 & 4 & 0.252 \\
\hline - Several outlets & 0.063 & 3 & 0.189 & 2 & 0.126 & 3 & 0.189 & 3 & 0.189 \\
\hline - Budget support & 0.063 & 4 & 0.252 & 3 & 0.189 & 3 & 0.189 & 3 & 0.189 \\
\hline - Cooperation & 0.048 & 4 & 0.252 & 3 & 0.144 & 4 & 0.192 & 3 & 0.144 \\
\hline $\begin{array}{l}\text { - Lecturer } \\
\text { Competence }\end{array}$ & 0.048 & 3 & 0.144 & 3 & 0.144 & 4 & 0.192 & 3 & 0.144 \\
\hline $\begin{array}{l}\text { - Facilities and } \\
\text { infrastructure }\end{array}$ & 0.063 & 4 & 0.252 & 4 & 0.252 & 3 & 0.189 & 4 & 0.252 \\
\hline - Curriculum & 0.063 & 3 & 0.189 & 4 & 0.252 & 3 & 0.189 & 3 & 0.189 \\
\hline \multicolumn{10}{|l|}{ Weaknesses } \\
\hline - Student Abilities & 0.032 & 3 & 0.096 & 3 & 0.096 & 4 & 0.128 & 3 & 0.096 \\
\hline - Student Background & 0.048 & 2 & 0.096 & 3 & 0.096 & 3 & 0.144 & 2 & 0.096 \\
\hline - Role of Alumni & 0.032 & 2 & 0.064 & 3 & 0.096 & 3 & 0.096 & 3 & 0.096 \\
\hline $\begin{array}{l}\text { - Foreign Language } \\
\text { Competence }\end{array}$ & 0.048 & 3 & 0.144 & 4 & 0.192 & 3 & 0.144 & 3 & 0.144 \\
\hline - Prodi promotion & 0.048 & 3 & 0.144 & 4 & 0.192 & 3 & 0.144 & 3 & 0.144 \\
\hline - Content of Courses & 0.032 & 3 & 0.096 & 3 & 0.096 & 2 & 0.064 & 2 & 0.064 \\
\hline $\begin{array}{l}\text { - Student's Choice of } \\
\text { Study Programs }\end{array}$ & 0.048 & 2 & 0.096 & 3 & 0.144 & 2 & 0.096 & 2 & 0.096 \\
\hline $\begin{array}{l}\text { - Supporting } \\
\text { activities }\end{array}$ & 0.032 & 3 & 0.096 & 3 & 0.096 & 3 & 0.096 & 3 & 0.096 \\
\hline - Cooperation in PKN & 0.032 & 3 & 0.096 & 3 & 0.096 & 4 & 0.128 & 3 & 0.096 \\
\hline $\begin{array}{l}\text { - Participation in } \\
\text { competitions }\end{array}$ & 0.048 & 3 & 0.144 & 3 & 0.144 & 4 & 0.192 & 3 & 0.144 \\
\hline
\end{tabular}




\begin{tabular}{|c|c|c|c|c|c|c|c|c|c|}
\hline \multicolumn{10}{|c|}{ Opportunities / Opportunities } \\
\hline $\begin{array}{l}\text { - Increasing high } \\
\text { school graduates }\end{array}$ & 0.056 & 4 & 0.224 & 3 & 0.168 & 4 & 0.224 & 4 & 0.224 \\
\hline $\begin{array}{l}\text { - Studying at } \\
\text { Vocational PT }\end{array}$ & 0.037 & 3 & 0.111 & 2 & 0.074 & 3 & 0.111 & 3 & 0.111 \\
\hline $\begin{array}{l}\text { - Development of the } \\
\text { Hospitality Industry }\end{array}$ & 0.056 & 2 & 0.112 & 2 & 0.112 & 3 & 0.168 & 3 & 0.168 \\
\hline - Alumni Spread & 0.056 & 2 & 0.112 & 2 & 0.112 & 3 & 0.168 & 3 & 0.168 \\
\hline $\begin{array}{l}\text { - There is a } \\
\text { scholarship }\end{array}$ & 0.074 & 2 & 0.148 & 3 & 0.222 & 4 & 0.296 & 4 & 0.296 \\
\hline - Wide promotion & 0.056 & 3 & 0.168 & 3 & 0.168 & 4 & 0.224 & 3 & 0.168 \\
\hline $\begin{array}{l}\text { - Extracurricular } \\
\text { activities }\end{array}$ & 0.056 & 3 & 0.168 & 3 & 0.168 & 4 & 0.224 & 3 & 0.168 \\
\hline - Job Opportunities & 0.056 & 4 & 0.224 & 3 & 0.168 & 4 & 0.224 & 3 & 0.168 \\
\hline $\begin{array}{l}\text { - relevant } \\
\text { competencies }\end{array}$ & 0.056 & 3 & 0.168 & 3 & 0.168 & 4 & 0.224 & 3 & 0.168 \\
\hline $\begin{array}{l}\text { - Opportunity to enter } \\
\text { the race }\end{array}$ & 0.056 & 3 & 0.168 & 2 & 0.112 & 4 & 0.224 & 2 & 0.112 \\
\hline \multicolumn{10}{|l|}{ Threats } \\
\hline $\begin{array}{l}\text { - PT which switched } \\
\text { to Polytechnic }\end{array}$ & 0.037 & 2 & 0.074 & 3 & 0.111 & 3 & 0.111 & 3 & 0.111 \\
\hline $\begin{array}{l}\text { - Opening of the } \\
\text { Hospitality Study } \\
\text { Program }\end{array}$ & 0.037 & 2 & 0.074 & 3 & 0.111 & 2 & 0.074 & 2 & 0.074 \\
\hline $\begin{array}{l}\text { - Announcement of } \\
\text { students at Univ. that } \\
\text { was earlier }\end{array}$ & 0.037 & 1 & 0.037 & 2 & 0.074 & 2 & 0.074 & 2 & 0.074 \\
\hline $\begin{array}{l}\text { - The existence of the } \\
\text { SBMPTNP }\end{array}$ & 0.055 & 2 & 0.110 & 3 & 0.165 & 1 & 0.055 & 2 & 0.110 \\
\hline $\begin{array}{l}\text { - Hospitality DIV } \\
\text { Program }\end{array}$ & 0.055 & 4 & 0.22 & 3 & 0.165 & 3 & 0.165 & 4 & 0.22 \\
\hline $\begin{array}{l}\text { - Food ordering } \\
\text { online }\end{array}$ & 0.055 & 2 & 0.110 & 2 & 0.110 & 1 & 0.055 & 2 & 0.110 \\
\hline $\begin{array}{l}\text { - The entrance exam } \\
\text { is still manual }\end{array}$ & 0.037 & 2 & 0.074 & 1 & 0.037 & 1 & 0.037 & 2 & 0.074 \\
\hline $\begin{array}{l}\text { - Competence of } \\
\text { graduates }\end{array}$ & 0.037 & 3 & 0.111 & 3 & 0.111 & 4 & 0.148 & 3 & 0.111 \\
\hline $\begin{array}{l}\text { - Needs to be an } \\
\text { undergraduate / S1 }\end{array}$ & 0.055 & 4 & 0.22 & 3 & 0.165 & 4 & 0.22 & 4 & 0.22 \\
\hline - Community image & 0.037 & 3 & 0.111 & 3 & 0.111 & 2 & 0.074 & 3 & 0.111 \\
\hline
\end{tabular}


224. Jurnal Administrare: Jurnal Pemikiran Ilmiah dan Pendidikan Administrasi Perkantoran
Volume 7 Number 2 July- December 2020. Pages 215-226

$\begin{array}{lllll}\text { Total } & 5.976 & 5.869 & 6.354 & 6.027\end{array}$

Based on the results of the strategy formulation and the predetermined priority scale, the development strategy of the Food and Beverage Service study program is compiled in 14 priority strategies out of the 20 formulated strategies, namely:

1. Maximizing the implementation of extra-curricular activities in improving student competence (W1, O7, O9)

2. Involving alumni regularly as Guest Lecturers to increase knowledge, insight, skills, and motivation to students so that they are proud of their study program (W1, W2, W7, O4)

3. Provide activities for students to use English optimally, for example when entering a restaurant, or when serving guests and in extra-curricular activities (W4, O7, O9)

4. Coordination between study programs is further improved so that the implementation of practice can run optimally (W6, W8, O9)

5. Cooperation with industry in implementing $\mathrm{PKN}$ is further enhanced including providing facilities to students (W9, O8, O9)

6. Providing orientation or hotel visits to new students (W2, T8)

7. More often provide training to the community or other service activities by involving students to improve the image or image (W5, W7, T10)

8. Prepare the study program to switch to the D-IV program by using the name of the study program "Restaurant Management" or Restaurant Management (W2, T9)

9. Promotional activities are further enhanced both offline and online by involving study programs to highlight all products, outlets, job opportunities, and graduate profiles (S1, $\mathrm{S} 5, \mathrm{O6}, \mathrm{O} 8)$

10. Cooperate with alumni in promoting study programs and providing information on job opportunities in the industries/companies where the alumni work. (S7, O4, O6, O8)

11. Involving students actively in every competition or event that can introduce study programs to the community (S6, O6, O10)

12. Curriculum reviews are carried out periodically based on industry needs (S3, S10, O9)

13. The study program must create a logo that accentuates products from the restaurant and not on services (S3, S5, T8, T10)

14. The study program creates profiles that further highlight products and competencies in restaurant management, including displaying top-level positions in restaurants, not service profiles that carry trays $(\mathrm{S} 3, \mathrm{~S} 5, \mathrm{~T} 8, \mathrm{~T} 10)$

\section{CONCLUSION}

Based on the results of the IFAS matrix with a weight of 1.0 , the weight score is 3,344 with a weight score for the strength factor of 2.304 while the factor for weakness is 1.040 . This shows that the strength factor of the study program is much greater than the weakness factor so that the study program has strengths or advantages that can be developed. The results of the EFAS matrix analysis show that with a weight of 1.0, a weight score of 2.818 is obtained, with 
details for the opportunity factor score of 1.714 while the threat factor is obtained 1.104. This shows that the opportunities that the study program has are greater than the threat factor so that the study program has a greater chance of being developed. Meanwhile, the QSPM matrix results obtained the TAS value which has been listed, namely the W - O Strategy getting the highest value, namely 6.354, the W - T Strategy which is 6,027 then the S - O Strategy which is 5,976 and finally the S-T Strategy which is 5,869. So that the development strategy of the MTH study program is compiled in 14 priority strategies from 20 strategies that have been formulated consisting of the W - O Strategy (5 strategies), the W - T Strategy (4 strategies), the S - O Strategy (3 strategies), and the S Strategy. - T (2 strategies).

\section{REFERENCES}

Astuti, R., Silalahi, R. L. R., \& Wijaya, G. D. P. (2015). Marketing Strategy Based on Marketing Mix Influence on Purchasing Decisions of Malang Apples Consumers at Giant Olympic Garden Mall (MOG), Malang City, East Java Province, Indonesia. Agriculture and Agricultural Science Procedia, 3, 67-71. https://doi.org/https://doi.org/10.1016/j.aaspro.2015.01.015

Botituhe, N., Akib, H., \& Gani, H. A. (n.d.). Strategy Formulation through Identification Of Asset Management Problem Of The Gorontalo City Government.

Boyd, W., \& Harper, M. P. (2000). Suatu Pendekatan Strategis dengan Orientasi Global. Jakarta: Erlangga, 133.

Evelyn, E. (2018). Analisis Manajemen Strategi Bersaing Dengan Matriks Ie, Matriks Swot Dan Matriks Qspm Pada Pt. Xyz. Jurnal Manajemen Bisnis dan Kewirausahaan, 2(4).

Herdiansyah, H. (2010). Metodologi penelitian kualitatif untuk ilmu-ilmu sosial. In Jakarta: Salemba Humanika.

Ibrahim, R., Boerhannoeddin, A., \& Kazeem Kayode, B. (2017). Organizational culture and development: Testing the structural path of factors affecting employees' work performance in an organization. Asia Pacific Management Review, 22(2), 104-111. https://doi.org/https://doi.org/10.1016/j.apmrv.2016.10.002

Klein, D. A. (2009). The strategic management of intellectual capital. Routledge.

Kurniawati, R., Triyanti, N., \& Daraba, D. (2019). Tourism Object Development Strategy in Rejang Lebong Regency Bengkulu Province. PINISI Discretion Review, 3(2), 143-150.

Prasodjo, T. (2020). Knowledge Management: Sustainable Human Resource Development in Public Sector Organizations. Jurnal Ad'ministrare, 6(2), 159-166.

Rangkuti, F. (2016). Personal SWOT Analysis Peluang di Balik Kesulitan. Jakarta: Gramedia.

Rasyid, A. R. (2020). Prototype of the Strategy for the Development of HR Competencies in the State Civil Service in Barru Regency. Jurnal Ilmiah Ilmu Administrasi Publik, 10(1), 133142.

Sedarmayanti. (2018). Tata Kerja dan Produktivitas Kerja. In Bandung, CV Mandar Maju.

Setyosari, P. (2012). Research Methods Education and Development. Jakarta: Kencana Prenada Media Group.

Sofjan, A. (2013). Strategic Management, Sustainable Competitive Advantages. Jakarta: PT. Raja Grapindo Persada.

Sugiyono. (2017). Pendekatan Kuantitatif, Kualitatif, Kombinasi, R\&D dan Penelitian Evaluasi. Bandung: Alfa Beta. 
226 Jurnal Administrare: Jurnal Pemikiran Ilmiah dan Pendidikan Administrasi Perkantoran Volume 7 Number 2 July- December 2020. Pages 215-226 